\title{
Tahapan Mendirikan Wirausaha Pendidikan Bagi Pemula
}

\author{
Erwinda Eka Prastyawati \\ Universitas Nahdlatul Ulama Sidoarjo
}

\section{PEMBUKAAN}

Sektor pendidikan mengalami banyak perubahan dalam beberapa tahun terakhir dan telah memberikan begitu banyak peluang baru. Hal ini tidak hanya bagi siswa tetapi juga bagi mereka yang memiliki karir dan wirausaha bisnis di bidang pendidikan. Dengan teknologi seperti kecerdasan buatan dan pembelajaran digital, sektor pendidikan telah mengalami perubahan total. Pendidikan sekarang telah melampaui batasnya dan tidak lagi terkait dengan pengajaran di sekolah saja. Berbagai layanan pendidikan baru telah muncul untuk meningkatkan standar industri pendidikan. Sehingga, para wirausahawan bersedia memberikan layanan pendidikan.

Dunia wirausaha menjadi trendi karena tampilan kesuksesan yang menyilaukan (Purnomo et al., 2019). Berikut adalah beberapa langkah yang dapat membantu Anda memulai bisnis layanan pendidikan untuk pemula.

\section{KELUARLAH DENGAN IDE BARU}

Seperti di semua bidang bisnis, dalam pendidikan juga, orang-orang dan pasar menyambut ide baru yang berguna bagi siswa. Wirausaha pendidikan perlu memberikan penekanan pada pentingnya ide baru. Dikatakan bahwa ide bisnis Anda harus membuat Anda terpesona. Untuk mengetahui ide baru Anda, pertama-tama pelajarilah pasar yang ada dengan hati-hati dan cari tahu materi pendidikan, teknik dll yang biasanya didapatkan oleh siswa. Pahami juga masalah yang mereka hadapi. Kemudian, cari tahu solusi apa yang dapat Anda tawarkan. Ini akan membantu Anda dalam merumuskan ide pendidikan yang dapat berubah menjadi bisnis yang berkembang. Jika Anda menemukan solusi yang baik, Anda dapat mengatur start-up dengan rasa panik dan tujuan (Ray, 2015).

\section{DAFTAR LAYANAN PENDIDIKAN}

Munculkan daftar layanan atau produk bisnis pendidikan yang ingin Anda tawarkan dan tambahkan harganya masing-masing (Brookins, 2019). Siswa perlu memahami apa yang diketahui dan apa yang diminta untuk memiliki kemampuan menjawab (Suci et al., 2018). Pendidikan Indonesia membutuhkan peningkatan akses, mutu dan relevansi pendidikan untuk memberi manfaat membangun bagi pendidikan dan rakyat Indonesia (Irawan et al., 2018). 


\section{TEMUKAN SISWA ANDA SECARA ONLINE}

Sekarang semuanya sudah diatur, sekarang saatnya untuk menyebarkan berita di semua sudut kanan internet untuk menemukan siswa potensial ke sekolah online Anda. Bagaimana Anda memasarkan akademi online Anda akan sampai ke audiens Anda. Anda harus memilih strategi yang fokus pada tempat perhatian mereka, dan menambahkan banyak nilai di muka (Johnson, 2019). Penerapan pembelajaran multimedia dapat meningkatkan prestasi siswa; dan tes menunjukkan bahwa prestasi belajar siswa kelas belajar multimedia lebih baik daripada siswa kelas konvensional (Iskandar, Rizal, Kurniasih, Sutiksno, \& Purnomo, 2018). Implementasi teknologi pembelajaran adalah salah satu cara yang diperlukan untuk menunjukkan kompetensi lulusan yang berkualitas di era industri 4.0. (Sudrajat et al., 2019).

Berikut ini beberapa kiat untuk membantu Anda memulai:

- Gunakan media sosial: Platform seperti Facebook dan Instagram saat ini sangat terfokus pada video. Anda dapat menggunakan penggoda dan cuplikan atau konten gaya pemasaran untuk menjangkau ribuan orang setiap hari.

- Leverage YouTube: Raksasa video ini juga bisa menjadi sumber lalu lintas ke video dan situs web Anda. Anda dapat membaca panduan lengkap kami tentang cara menggunakan YouTube untuk menjual video Anda secara online di sini.

- Membangun milis: Email masih merupakan cara nomor satu untuk berhubungan dengan pelanggan potensial. Beri orang pilihan untuk bergabung dengan buletin Anda di semua halaman Anda.

\section{MEMPERSIAPKAN RENCANA BISNIS}

Rencana bisnis wirausaha pendidikan adalah cetak biru yang menggambarkan visi dan tujuan perusahaan dan strategi untuk mencapai tujuan tersebut. Apakah Anda memutuskan untuk membuka sekolah atau layanan pelatihan, atau bahkan platform e-learning, rencana bisnis wirausaha pendidikan adalah yang harus dimiliki sebelum Anda terjun ke bisnis (Arya, 2019). Manajemen adalah proses mengarahkan atau menjalankan bisnis, serta. sekelompok manajer atau direktur (Purnomo, Putri, \& Rosyidah, 2017).

\section{PASTIKAN ANDA MEMILIKI KUALIFIKASI YANG DISYARATKAN}

Untuk keperluan panduan ini, kami akan berasumsi bahwa mayoritas orang yang ingin memulai bisnis pendidikan akan mengajarkan keterampilan informal, seperti memberikan tips dan saran kehidupan. Contoh kursus untuk keterampilan informal mungkin might Bagaimana menjadi viral di Instagram, Bagaimana menulis buku digital Amazon yang sukses, atau Cara membuat film Anda sendiri 
dengan iPhone. Ini adalah keterampilan yang Anda tidak perlu kualifikasi untuk mengajar, dan merupakan masalah pengalaman sebanyak fakta. Jika Anda ingin memberikan pendidikan yang lebih formal (seperti bagaimana lulus kursus yang ada dari lembaga penguji), kemungkinan Anda harus memenuhi syarat dan terdaftar untuk melakukannya. Bahkan dalam kasus di mana legal untuk memberikan pelatihan tidak terdaftar atau tidak disetujui untuk kursus ini, Anda akan merasa sangat sulit untuk mengamankan pelanggan untuk kursus yang Anda mungkin tidak memenuhi syarat untuk mengajar. Anda juga biasanya harus membayar biaya untuk menjadi tuan rumah kursus dan persentase pada setiap pesanan individu, yang akan memotong garis bawah Anda. Dalam kasus di mana bidang keahlian Anda adalah subjek yang membutuhkan kualifikasi tambahan dan struktur kursus yang ketat, mungkin ada cara lain untuk mendekati pendidikan online. Jika Anda seorang Pengawas Situs, misalnya, Anda mungkin tidak memenuhi syarat untuk memberikan pelatihan Pengawas Situs, atau dapat menawarkan kursus secara online. Namun Anda bisa memberikan kursus yang lebih umum, menawarkan tips tentang cara meningkatkan sebagai Pengawas Situs untuk orang-orang yang kurang berpengalaman dalam peran tersebut (Eurostart Entreprises, 2015). Teknologi komputer telah menawarkan peluang baru dalam proses pembelajaran baik di ruang kelas, pembelajaran jarak jauh atau belajar mandiri (Simarmata et al., 2018).

\section{INTERAKSI JARINGAN PROFESIONAL INDUSTRI PENDIDIKAN}

Bergabung dengan kelompok profesional dan jejaring lokal, terutama yang terkait dengan wirausaha pendidikan. Grup-grup industri pendidikan ini akan memberi Anda kesempatan untuk mempromosikan bisnis pendidikan Anda ke profesional lain yang mungkin dapat merujuk layanan Anda. Anda juga dapat menemukan peluang untuk bermitra dengan perusahaan pendidikan yang melayani target pasar yang sama dengan Anda di bisnis pendidikan, tetapi yang bukan pesaing (Brookins, 2019). Dunia dan masyarakat membutuhkan kewirausahaan (Setyawati, Purnomo, Irawan, Tamyiz, \& Sutiksno, 2018).

\section{KESIMPULAN}

Beberapa langkah yang dapat membantu Anda memulai bisnis layanan pendidikan untuk pemula yaitu interaksi jaringan profesional, kualifikasi yang disyaratkan, rencana bisnis, menemukan siswa, daftar layanan, dan ide baru.

\section{REFERENCES}

Arya, N. (2019). Things to Consider While Starting an Educational Services Business. Retrieved November 13, 2019, from https://www.franchiseindia.com/education/things-to-consider-while- 
starting-an-educational-services-business.12980

Brookins, M. (2019). How to Start an Education Related Small Business. Retrieved November 14, 2019, from https://smallbusiness.chron.com/start-educationrelated-small-business-2239.html

Eurostart Entreprises. (2015). How to start an online education business.

Retrieved November 15, 2019, from

https://www.eurostartentreprises.com/business-advice/item/194-how-tostart-an-online-education-business

Irawan, D. E., Purnomo, A., Sutiksno, D. U., Abraham, J., Alamsyah, A., Saputra, D. H., ... Rosyidah, E. (2018). Kajian Pendidikan Tinggi IDRI untuk DPR RI dan Ristek Dikti 2018. Bandung: ITB Press.

Iskandar, A., Rizal, M., Kurniasih, N., Sutiksno, D. U., \& Purnomo, A. (2018). The Effects of Multimedia Learning on Students Achievement in Terms of Cognitive Test Results. Journal of Physics: Conference Series, 1114(1), 012019. https://doi.org/10.1088/1742-6596/1114/1/012019

Johnson, J. (2019). How to Start a Profitable Online School in 5 Easy Steps. Retrieved December 5, 2019, from https://www.uscreen.tv/blog/how-tostart-create-online-school/

Purnomo, A., Asitah, N., Rosyidah, E., Septianto, A., Daryanti, M. D., \& Firdaus, M. (2019). Generasi Z sebagai Generasi Wirausaha. https://doi.org/10.31227/osf.io/4m7kz

Purnomo, A., Putri, R. A., \& Rosyidah, E. (2017). Kamus Manajemen Sumber Daya Manusia. Sidoarjo: UNUSIDA Press.

Ray, H. (2015). 5 Easy Steps to Successfully Launch an Educational Startup. Retrieved November 14, 2019, from https://www.designhill.com/designblog/easy-steps-to-successfully-launch-an-educational-startup/

Setyawati, I., Purnomo, A., Irawan, D. E., Tamyiz, M., \& Sutiksno, D. U. (2018). A Visual Trend of Literature on Ecopreneurship Research Overviewed within The Last two Decades. Journal of Entrepreneurship Education, 21(4), 1-7. Retrieved from https://www.abacademies.org/articles/a-visual-trend-ofliterature-on-ecopreneurship-research-overviewed-within-the-last-twodecades-7468.html

Simarmata, J., Dharma, M., Putra Nasution, T., Manurung, R. T., Lubis, M. A., Kurniasih, N., ... Rahim, R. (2018). Prototype Application Multimedia Learning for Teaching Basic English. International Journal of Engineering \& Technology, 714(2), 264-266. https://doi.org/10.14419/ijet.v7i2.12.14689

Suci, S. H. A., Rosyidah, E., Asitah, N., Aini, N., Murni, A. W., Anam, F., ... Kuraesin, A. D. (2018). Learning from Picture and Picture Action Research : Enhancement of Counting Ability on Division of Numbers for Primary School Students. Journal of Physics: Conference Series, 1114(1), 012044. https://doi.org/10.1088/1742-6596/1114/1/012044

Sudrajat, D., Achdisty, M., Kurniasih, N., Roslina, Parwito, Mulyati, S., ... Sallu, S. (2019). The Implementation of Innovation in Educational Technology to Improve The Quality of Website Learning in Industrial Revolution Era 4.0 Using Waterfall Method. Journal of Physics: Conference Series, 1364, 
012044. https://doi.org/10.1088/1742-6596/1364/1/012044 